\title{
Myceligenerans crystallogenes sp. nov., isolated from Roman catacombs
}

Correspondence

Ingrid Groth

Ingrid.Groth@hki-jena.de

\author{
Ingrid Groth, ${ }^{1}$ Peter Schumann, ${ }^{2}$ Barbara Schütze, ${ }^{1}$ Juan M. Gonzalez, \\ Leonila Laiz, ${ }^{3}$ Maija-Liisa Suihko ${ }^{4}$ and Erko Stackebrandt ${ }^{2}$ \\ ${ }^{1}$ Leibniz-Institut für Naturstoff-Forschung und Infektionsbiologie e. V., Hans-Knöll-Institut, \\ Beutenbergstrasse 11a, 07745 Jena, Germany \\ ${ }^{2} \mathrm{DSMZ}$ - Deutsche Sammlung von Mikroorganismen und Zellkulturen GmbH, Mascheroder \\ Weg 1b, 38124 Braunschweig, Germany \\ ${ }^{3}$ Instituto de Recursos Naturales y Agrobiologia, CSIC, Apartado 1052, 41080 Sevilla, Spain \\ ${ }^{4}$ VTT Biotechnology, PO Box 1500, FI-02044 VTT, Finland
}

The genus Myceligenerans was proposed recently by Cui et al. (2004) for a single strain that was isolated from an alkaline salt marsh soil in China. The type strain of the species Myceligenerans xiligouense, strain XLG9A10.2 $2^{\mathrm{T}}$ (=DSM $15700^{\mathrm{T}}$ ), forms a distinct phylogenetic line within the family Promicromonosporaceae, suborder Micrococcineae, order Actinomycetales, and shares 94.8-95.1\% 16S rRNA gene sequence similarity with representatives of the genus Promicromonospora Krasil'nikov et al. 1961 and 94·4-95·7\% similarity with strains of the genera Xylanimonas Rivas et al. 2003, Xylanibacterium Rivas et al. 2004 and Isoptericola Stackebrandt et al. 2004. M. xiligouense shares the ability to hydrolyse xylan with members of the last three genera and with Xylanimicrobium pachnodae (Stackebrandt \& Schumann, 2004).

From different sampling sites in the Roman catacombs of Domitilla and San Callisto, three morphologically similar

Published online ahead of print on 30 September 2005 as DOI 10.1099/ijs.0.63756-0.

The GenBank/EMBL/DDBJ accession number for the 16S rRNA gene sequence of strain CD12E2-27 ${ }^{\top}\left(=\mathrm{HKI} 0369^{\top}\right)$ is AY928181.

Tables showing the physiological test results for the strains in this study are available as supplementary material in IJSEM Online. actinobacteria were isolated that were able to degrade xylan and to produce crystals of iodinin (1,6-phenazinediol 5,10dioxide). Preliminary phylogenetic data obtained from $16 \mathrm{~S}$ rRNA gene sequence comparison indicated a close relationship with M. xiligouense (DSM $15700^{\mathrm{T}}$ ). Therefore a polyphasic taxonomic study was carried out to establish the taxonomic position of these isolates.

Strain CD12E2-27 $7^{\mathrm{T}}\left(=\right.$ HKI $\left.0369^{\mathrm{T}}\right)$ was isolated from a sample of tufa collected in the first arcosolium behind the entrance of the Roman catacomb of Domitilla using peptone/yeast extract/brain heart infusion agar (Yokota et al., 1993) and a standard dilution plate procedure. Strain CD12Tz-28 (=HKI 0371=VTT E-032288) was obtained from the stone surface of the burial chamber at the same place by touching the stone with a sterile cotton swab and suspending the adherent bacteria in 1:10-diluted organic medium 79 (Prauser \& Falta, 1968). Aliquots of this suspension were spread on peptone/yeast extract/brain heart infusion agar plates and incubated at $28^{\circ} \mathrm{C}$ for 10 days. Strain CSC13Tb-79 (=HKI 0372=VTT E-032289) was isolated from a fresco in the cubiculum of Oceano, catacomb of San Callisto, Rome, using the same procedure and humic acid agar (Hayakawa \& Nonomura, 1987) for growth. 
(In the following text and in the tables and figures, only the HKI numbers are used for the isolates.)

General laboratory cultivation, morphological studies, determination of the optimal growth parameters (temperature, $\mathrm{pH}$, oxygen requirements) and analysis of the susceptibility to antibiotics were performed using solid or liquid organic medium 79 and an incubation temperature of $28^{\circ} \mathrm{C}$. Cell morphology and cell dimensions were examined by phase-contrast microscopy using a Zeiss Axioscope 2 microscope equipped with image-analysing software (Axio Vision 2.05; Zeiss). The colony morphology of 2-10-day-old cultures was studied using an Olympus stereo microscope. Standard physiological tests were carried out according to the methods described by Cowan \& Steel (1965), Gordon et al. (1974), Lanyi (1987) and Smibert \& Krieg (1994). Acid production from carbon sources was studied using the API $50 \mathrm{CH}$ system and API $50 \mathrm{CHB} / \mathrm{E}$ medium (bioMérieux) according to the manufacturer's instructions (incubation times of up to 7 days). API ZYM galleries (bioMérieux) were used to study enzymic activities. Additionally, the utilization of carbon sources was tested using Biolog GP2 MicroPlates and MicroLog computer software (Biolog Identification System). The cell density of the inoculum for the GP2 MicroPlates was adjusted to the range specified by the Biolog turbidity standard GP-COC/GP-ROD/GN-FAS (20\%T). Xylanolytic activity was determined on medium II, described by Cazemier et al. (2003), and using incubation times of up to 28 days. Susceptibility to antibiotics was examined by placing antibiotic discs (Difco) on agar plates that were seeded with suspensions of the test strains grown in a soft agar layer for $24 \mathrm{~h}$ at $28^{\circ} \mathrm{C}$. Oxygen requirements were studied with the GENbag microaer and GENbag anaer incubation systems (bioMérieux). The $\mathrm{pH}$ range for growth was established by using liquid medium adjusted to $\mathrm{pH}$ values between 4 and 11 with either $1 \mathrm{M} \mathrm{HCl}$ or $20 \%(\mathrm{w} / \mathrm{v})$ $\mathrm{Na}_{2} \mathrm{CO}_{3}$ solution and then incubating the samples at $28^{\circ} \mathrm{C}$ for up to 10 days. The reference strains used for comparisons in physiological tests and DNA-DNA pairing studies were Isoptericola variabilis DSM $10177^{\mathrm{T}}$, Xylanimicrobium pachnodae DSM $12657^{\mathrm{T}}$, Xylanimonas cellulosilytica DSM $15894^{\mathrm{T}}$ and M. xiligouense DSM $15700^{\mathrm{T}}$. Biomass for chemotaxonomic and molecular systematic studies was prepared by growing the strains in shake flasks containing liquid organic medium 79 or Bacto tryptic soy broth (Sigma-Aldrich) for 24-48 h. Stock cultures of the three isolates, HKI $0369^{\mathrm{T}}$, HKI 0371 and HKI 0372, in liquid organic medium 79 supplemented with $5 \%$ DMSO were maintained either in the vapour phase of liquid nitrogen or at $-80^{\circ} \mathrm{C}$ as a $1: 1$ mixture of the liquid culture and a glycerol medium that consisted of $\mathrm{K}_{2} \mathrm{HPO}_{4}(1 \cdot 26 \%), \mathrm{KH}_{2} \mathrm{PO}_{4}$ $(0.36 \%), \mathrm{MgSO}_{4}(0.01 \%)$, sodium citrate $(0.09 \%)$, $\left(\mathrm{NH}_{4}\right)_{2} \mathrm{SO}_{4}(0 \cdot 18 \%)$ and glycerol $(8 \cdot 8 \%)$.

The colonies of the three isolates under study were white to cream in colour, circular, convex and smooth (with diameters of about $1 \mathrm{~mm}$ ). Larger wrinkled colonies with diameters of $2-4 \mathrm{~mm}$ were also observed. The colonies were distinguished from those of M. xiligouense DSM $15700^{\mathrm{T}}$ by their white to cream colour, which never changed to yellow. Aerial mycelium was absent. The three organisms produced spore-like cells in the substrate mycelium after growth on solid organic medium 79: these cells were similar to those described for M. xiligouense by Cui et al. (2004). In liquid cultures, a well-developed primary mycelium was produced within $8-24 \mathrm{~h}$ (width $0 \cdot 5-0 \cdot 7 \mu \mathrm{m}$ ); this underwent fragmentation into irregular non-motile rods and cocci after about $48 \mathrm{~h}$ cultivation.

The morphological and physiological similarities of the three strains under study underline the genomic coherence of these isolates (see Supplementary Tables S1 and S2 available in IJSEM Online). Although the novel strains share numerous physiological characteristics with $M$. xiligouense DSM $15700^{\mathrm{T}}$, they could be readily distinguished from the latter by means of the physiological characteristics listed in Table 1. Full details of the results of the physiological tests are available as Supplementary Tables S1 and S2 in IJSEM Online.

Table 1. Physiological characteristics that differentiate the strains of M. crystallogenes from M. xiligouense DSM $15700^{\top}$

- , Negative; + , positive; $(+)$, weakly positive; $\mathrm{v}$, variable.

\begin{tabular}{|c|c|c|}
\hline Test & $\begin{array}{l}\text { M. xiligouense } \\
\text { DSM } 15700^{\mathrm{T}}\end{array}$ & M. crystallogenes \\
\hline $\begin{array}{l}\text { Growth in the presence } \\
\text { of } 8.0 \% \mathrm{NaCl}\end{array}$ & $(+)$ & - \\
\hline \multicolumn{3}{|l|}{ Decomposition of: } \\
\hline Tyrosine & - & + \\
\hline Urea & - & + \\
\hline \multicolumn{3}{|l|}{ Utilization of: } \\
\hline Aconitate & - & + \\
\hline Citrate & - & $\mathrm{V}^{*}$ \\
\hline \multicolumn{3}{|l|}{ Enzyme assay (API ZYM) } \\
\hline Trypsin & $(+)$ & $\mathrm{v} \dagger$ \\
\hline \multicolumn{3}{|l|}{ Antibiotic susceptibility } \\
\hline Ampicillin $(10 \mu \mathrm{g})$ & - & + \\
\hline Kanamycin $(30 \mu \mathrm{g})$ & - & $\mathrm{v} \dagger$ \\
\hline Penicillin G (10 IU) & - & + \\
\hline Polymyxin B (300 IU) & - & + \\
\hline \multicolumn{3}{|l|}{$\begin{array}{l}\text { Biolog GP2 MicroPlate } \\
(24 \mathrm{~h} \text { incubation })\end{array}$} \\
\hline Glycogen & + & - \\
\hline Arbutin & + & - \\
\hline Methyl $\alpha$-D-galactoside & + & - \\
\hline D-Sorbitol & + & - \\
\hline L-Lactic acid & + & $\mathrm{v} \dagger$ \\
\hline L-Alaninamide & + & - \\
\hline Uridine & + & - \\
\hline Nitrate reduction & - & + \\
\hline
\end{tabular}

*The type strain reacts positively.

$\dagger$ The type strain reacts negatively. 
The optimal growth parameters of the three catacomb isolates corresponded well with the data given by Cui et al. (2004) for M. xiligouense DSM $15700^{\mathrm{T}}$. However, in this study growth at 6 and $42^{\circ} \mathrm{C}$, at pH 5 and 10 and at a $\mathrm{NaCl}$ concentration of $10 \%(\mathrm{w} / \mathrm{v})$ was not observed for strain DSM $15700^{\mathrm{T}}$ or for the three isolates, as shown in Supplementary Table S1. Furthermore, it should be mentioned that differentiation between the isolates and M. xiligouense DSM $15700^{\mathrm{T}}$ using the API $50 \mathrm{CHB} / \mathrm{E}$ kit was not possible because of the generally weakly expressed metabolic activity in all strains. The results (data not shown) obtained at different incubation temperatures $\left(28\right.$ and $\left.35^{\circ} \mathrm{C}\right)$ did not allow an unambiguous interpretation (exceptions were the utilization of aesculin and arbutin). Weak activities were also observed in the utilization of carbon sources provided in the Biolog GP2 MicroPlates. The low colour intensities in the wells and the mycelial growth of the strains under study contributed to the fact that numerous reactions had to be considered as variable.

For sequence analysis of the 16S rRNA gene, the genomic DNA was extracted by following the method described by Marmur (1961). PCR-mediated amplification of the $16 \mathrm{~S}$ rRNA gene, sequencing of the amplified DNA fragment and phylogenetic analysis were carried out as described previously (Groth et al., 2005).

Phylogenetic analysis of the almost-complete 16S rRNA gene (1437 bases) revealed that strain HKI $0369^{\mathrm{T}}$ is a member of the family Promicromonosporaceae, showing between 93.0 and $97.9 \%$ similarity with its members. The highest level of relatedness (97.9\%) was obtained with $M$. xiligouense DSM $15700^{\mathrm{T}}$. A bootstrap value of 100 confirmed the isolated position of the two strains within the radiation of the Promicromonosporaceae (Fig. 1).

For DNA-DNA relatedness studies, DNA was isolated using a French pressure cell (Thermo Spectronic) and was purified by chromatography on hydroxyapatite as described by Cashion et al. (1977). DNA-DNA hybridization was carried out as described by De Ley et al. (1970), incorporating the modifications described by Huß et al. (1983), using a model Cary 100 Bio UV/VIS-spectrophotometer equipped with a Peltier-thermostatted $6 \times 6$ multicell changer and a temperature controller with an in situ temperature probe (Varian).

Ribotyping was performed using the standard method of the automated ribotyping device RiboPrinter System (DuPont Qualicon) according to the manufacturer's instructions, as described by Bruce (1996). The restriction enzyme used was PvuII (DuPont Qualicon).

The three catacomb isolates shared a $16 \mathrm{~S}$ rRNA gene similarity of $99 \cdot 9 \%$. This close phylogenetic relationship was underlined by the results of the riboprint analysis (Fig. 2). Strains HKI $0369^{\mathrm{T}}$ and HKI 0372 showed identical riboprint patterns and were affiliated to the same ribogroup. In strain HKI 0371, an additional band occurred that was unique to this strain and which did not occur in the pattern of $M$. xiligouense DSM $15700^{\mathrm{T}}$.

Strain HKI $0369^{\mathrm{T}}$ and the type strain of M. xiligouense DSM $15700^{\mathrm{T}}$ shared a $16 \mathrm{~S}$ rRNA gene similarity of $98 \%$, which corresponded to a low level of DNA-DNA similarity [14.4 and $13.3 \%$, measurement in duplicate; hybridization buffer, $2 \times$ SSC $+10 \%(\mathrm{v} / \mathrm{v})$ formamide; hybridization temperature, $68^{\circ} \mathrm{C}$. These low values together with the pronounced differences in the riboprint patterns between the three strains under study and $M$. xiligouense clearly indicate that the catacomb isolates and M. xiligouense DSM $15700^{\mathrm{T}}$ represent different genospecies.

The following chemotaxonomic characteristics were determined as described previously: the structure of the peptidoglycan (Schleifer \& Kandler, 1972; Schleifer, 1985; MacKenzie, 1987; Groth et al., 1996); the muramic acid type (Uchida \& Aida, 1984); the whole-cell sugars (Becker et al., 1965; Saddler et al., 1991); the menaquinones (Groth et al., 1996); the polar lipids (Minnikin et al., 1979; Collins \& Jones, 1980); and the mycolic acids (Minnikin et al., 1975).

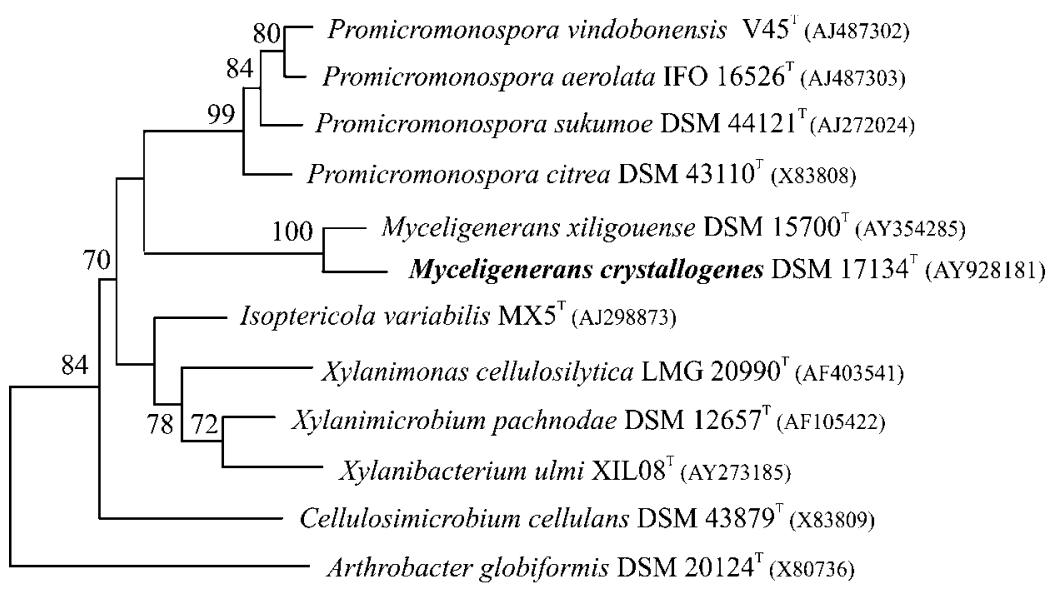

1.0
Fig. 1. Phylogenetic relatedness among members of the genera Myceligenerans, Isoptericola, Xylanimonas, Xylanimicrobium, Xylanibacterium, Cellulosimicrobium and Promicromonospora, based upon $16 \mathrm{~S}$ rRNA gene sequence comparison. Arthrobacter globiformis DSM 20124 ${ }^{\top}$ (X80736) was used as the outgroup. The dendrogram was generated by neighbour-joining analysis (Felsenstein, 1993). Numbers within the dendrogram indicate the percentages of occurrence of the branching order in 500 bootstrapped trees (only values of $50 \%$ and above are shown). Bar, 1 nucleotide substitution per 100 nucleotides. 


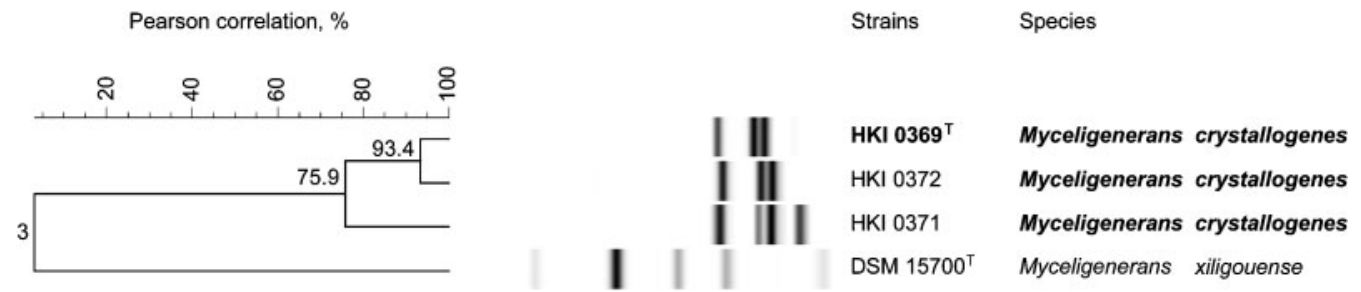

Fig. 2. Riboprint patterns of the three catacomb isolates and M. xiligouense DSM $15700^{\top}$. The dendrogram was constructed using the Pearson correlation coefficient and UPGMA with the software package BioNumerics (Applied Maths).

The fatty acid profile was determined using the MIDI system (Agilent).

The chemotaxonomic characteristics of the catacomb isolates were consistent with their affiliation to the genus Myceligenerans. The peptidoglycan of strain HKI $0369^{\mathrm{T}}$ contained $N$-acetylated muramic acid and corresponded to type A4 $\alpha$, L-Lys-L-Thr-D-Glu (A11.57 according to http:// www.dsmz.de/species/murein.htm). This type has been found in members of the family Cellulomonadaceae and from members of the family Promicromonosporaceae only in the genus Myceligenerans. The organisms under study shared with M. xiligouense DSM $15700^{\mathrm{T}}$ the characteristic sugars analysed in whole-cell hydrolysates, the major phospholipids and the predominant fatty acids [anteiso$\mathrm{C}_{15: 0}(54 \cdot 4 \mathrm{~mol} \%)$, iso- $\mathrm{C}_{15: 0}(18 \cdot 5 \mathrm{~mol} \%)$ and iso- $\mathrm{C}_{16: 0}$ $(16.5 \mathrm{~mol} \%)]$. The minor fatty acids were iso- $\mathrm{C}_{14: 0}$ $(4 \cdot 8 \mathrm{~mol} \%)$ and anteiso- $\mathrm{C}_{17: 0}(3.7 \mathrm{~mol} \%)$. The polar lipids were identified as diphosphatidylglycerol, phosphatidylglycerol, two unknown phospholipids and three unknown glycolipids. In contrast to the data given by Cui et al. (2004), phosphatidylinositol was not detected in preparations of $M$. xiligouense DSM $15700^{\mathrm{T}}$ or in those of the three isolates. The three strains under study could be differentiated from M. xiligouense by the patterns of their menaquinones. Strain HKI $0369^{\mathrm{T}}$ was characterized by the major menaquinones MK-9 $\left(\mathrm{H}_{8}\right)$, MK- $9\left(\mathrm{H}_{4}\right)$, MK- $9\left(\mathrm{H}_{6}\right)$ and MK-9 $\left(\mathrm{H}_{2}\right)$, with peak areas of $36: 19: 16: 13$, and the minor amounts of MK- $8\left(\mathrm{H}_{4}\right)$, MK-9 and MK-8 $\left(\mathrm{H}_{2}\right)$ (peak areas $6: 3: 1)$, while for $M$. xiligouense DSM $15700^{\mathrm{T}}$, the major menaquinones were MK- $9\left(\mathrm{H}_{4}\right)$ and MK- $9\left(\mathrm{H}_{6}\right)$.

The DNA G + C value for strain HKI $0369^{\mathrm{T}}$, determined by HPLC according to Groth et al. (1996), was $72 \cdot 3 \mathrm{~mol} \%$.

It is evident from the genotypic and phenotypic data that the three strains from the Roman catacombs merit recognition as a novel species in the genus Myceligenerans. The name proposed for this new taxon is Myceligenerans crystallogenes sp. nov.

\section{Description of Myceligenerans crystallogenes sp. nov.}

Myceligenerans crystallogenes [crys.tall.o.ge'nes. Gr. n. krustallos crystal; Gr. v. gennao produce; N.L. neut. adj. crystallogenes producing crystals of iodinin (1,6-phenazinediol 5,10-dioxide)].

Gram-positive, aerobic to microaerophilic actinomycete with a well-developed primary mycelium (diameter of hyphae $0 \cdot 5-0 \cdot 7 \mu \mathrm{m}$ ) that undergoes fragmentation into short, irregular, non-motile rods and cocci in the stationary growth phase. Aerial mycelium is absent. Spore-like cells occur in the substrate mycelium. Colonies on organic medium 79 are wrinkled, circular, smooth and white to cream (diameter about 1-4 mm). Grows between 10 and $40{ }^{\circ} \mathrm{C}$ (optimal growth is at $28^{\circ} \mathrm{C}$ ) and at $\mathrm{pH}$ values in the range $\mathrm{pH} 6-9 . \mathrm{NaCl}$ in the culture medium is well tolerated up to $5 \%$. Physiological characteristics (utilization of carbohydrates, enzymic activities and susceptibility to antibiotics) are listed in Supplementary Tables S1 and S2 in IJSEM Online. The peptidoglycan type is A4 $\alpha$, L-Lys-L-Thr-D-Glu. The whole-cell sugars are glucose, mannose and galactose. The acyl type is acetyl. The menaquinones are MK-9 $\left(\mathrm{H}_{8}\right)$, MK-9 $\left(\mathrm{H}_{4}\right)$, MK-9 $\left(\mathrm{H}_{6}\right)$, MK-9 $\left(\mathrm{H}_{2}\right)$ and minor amounts of MK-8 $\left(\mathrm{H}_{4}\right)$, MK-9 and MK- $8\left(\mathrm{H}_{2}\right)$. The predominant fatty acids are anteiso- $\mathrm{C}_{15: 0}$, iso- $\mathrm{C}_{15: 0}$ and iso- $\mathrm{C}_{16: 0}$. The phospholipids are diphosphatidylglycerol, phosphatidylglycerol, two unknown phospholipids and three unknown glycolipids. Mycolic acids are absent. The DNA G $+\mathrm{C}$ content is $72 \cdot 0-72 \cdot 3 \mathrm{~mol} \%$ (type strain, $72 \cdot 3 \mathrm{~mol} \%$ ).

The type strain is $\mathrm{CD} 12 \mathrm{E} 2-27^{\mathrm{T}}\left(=\mathrm{HKI} 0369^{\mathrm{T}}=\mathrm{DSM}\right.$ $\left.17134^{\mathrm{T}}=\mathrm{NCIMB} 14061^{\mathrm{T}}=\mathrm{VTT} \mathrm{E}-032285^{\mathrm{T}}\right)$, which was isolated from the catacomb of Domitilla in Rome, Italy.

\section{Acknowledgements}

This work was supported by the EC Programme 'Energy, Environment and Sustainable Development', in the framework of the CATS project (contract EVK4-CT-2000-00028). We are grateful to Christiane Weigel, Carmen Schult, Renate Schön and Helena Hakuli for excellent technical assistance.

\section{References}

Becker, B., Lechevalier, M. P. \& Lechevalier, H. A. (1965). Chemical composition of cell-wall preparations from strains of various formgenera of aerobic actinomycetes. Appl Microbiol 13, 236-243.

Bruce, J. (1996). Automated system rapidly identifies and characterizes microorganisms in food. Food Technol 50, 77-81. 
Cashion, P., Holder-Franklin, M. A., McCully, J. \& Franklin, M. (1977). A rapid method for the base ratio determination of bacterial DNA. Anal Biochem 81, 461-466.

Cazemier, A. E., Verdoes, J. C., Reubsaet, F. A. G., Hackstein, J. H. P., van der Drift, C. \& Op den Camp, H. J. M. (2003). Promicromonospora pachnodae sp. nov., a member of the (hemi)cellulolytic hindgut flora of larvae of the scarab beetle Pachnoda marginata. Antonie Van Leeuwenhoek 83, 135-148.

Collins, M. D. \& Jones, D. (1980). Lipids in the classification and identification of coryneform bacteria containing peptidoglycans based on 2,4-diaminobutyric acid. J Appl Bacteriol 48, 459-470.

Cowan, S. T. \& Steel, K. J. (1965). Manual for the Identification of Medical Bacteria. Cambridge: Cambridge University Press.

Cui, X., Schumann, P., Stackebrandt, E., Kroppenstedt, R. M., Pukall, R., Xu, L., Rohde, M. \& Jiang, C. (2004). Myceligenerans xiligouense gen. nov., sp. nov., a novel hyphae-forming member of the family Promicromonosporaceae. Int J Syst Evol Microbiol 54, 1287-1293.

De Ley, J., Cattoir, H. \& Reynaerts, A. (1970). The quantitative measurement of DNA hybridization from renaturation rates. Eur J Biochem 12, 133-142.

Felsenstein, J. (1993). PHYLIP (phylogeny inference package), version 3.5.1. Distributed by the author, Department of Genome Sciences, University of Washington, Seattle, USA.

Gordon, R. E., Barnett, D. A., Handerhan, J. E. \& Pang, C. H.-N. (1974). Nocardia coeliaca, Nocardia autotrophica, and the nocardin strain. Int J Syst Bacteriol 24, 54-63.

Groth, I., Schumann, P., Weiss, N., Martin, K. \& Rainey, F. A. (1996). Agrococcus jenensis gen. nov., sp. nov., a new genus of actinomycetes with diaminobutyric acid in the cell wall. Int J Syst Bacteriol 46, 234-239.

Groth, I., Schumann, P., Schütze, B., Gonzalez, J. M., Laiz, L., SaizJimenez, C. \& Stackebrandt, E. (2005). Isoptericola hypogeus sp. nov., isolated from the Roman catacomb of Domitilla. Int J Syst Evol Microbiol 55, 1715-1719.

Hayakawa, M. \& Nonomura, H. (1987). Humic acid-vitamin agar, a new medium for the selective isolation of soil actinomycetes. J Ferment Technol 65, 501-509.

Huß, V. A. R., Festl, H. \& Schleifer, K. H. (1983). Studies on the spectrophotometric determination of DNA hybridization from renaturation rates. Syst Appl Microbiol 4, 184-192.

Krasil'nikov, N. A., Kalakoutskii, L. V. \& Kirillova, N. F. (1961). New genus of the Actinomycetales: Promicromonospora gen. nov. Izv Akad Nauk SSSR Ser Biol 1, 107-112 (in Russian).

Lanyi, B. (1987). Classical and rapid identification methods for medically important bacteria. Methods Microbiol 19, 1-67.

MacKenzie, S. L. (1987). Gas chromatographic analysis of amino acids as the $N$-heptafluorobutyryl isobutyl esters. J Assoc Off Anal Chem 70, 151-160.
Marmur, J. (1961). A procedure for the isolation of deoxyribonucleic acid from microorganisms. J Mol Biol 3, 208-218.

Minnikin, D. E., Alshamaony, L. \& Goodfellow, M. (1975). Differentiation of Mycobacterium, Nocardia, and related taxa by thin-layer chromatographic analysis of whole-organism methanolysates. J Gen Microbiol 88, 200-204.

Minnikin, D. E., Collins, M. D. \& Goodfellow, M. (1979). Fatty acid and polar lipid composition in the classification of Cellulomonas, Oerskovia and related taxa. J Appl Bacteriol 47, 87-95.

Prauser, H. \& Falta, R. (1968). Phage sensitivity, cell wall composition and taxonomy of actinomycetes. Z Allg Mikrobiol 8, 39-46 (in German).

Rivas, R., Sánchez, M., Trujillo, M. E., Zurdo-Piñeiro, J. L., Mateos, P. F., Martínez-Molina, E. \& Velázquez, E. (2003). Xylanimonas cellulosilytica gen. nov., sp. nov., a xylanolytic bacterium isolated from a decayed tree (Ulmus nigra). Int J Syst Evol Microbiol 53, 99-103.

Rivas, R., Trujillo, M. E., Schumann, P., Kroppenstedt, R. M., Sánchez, M., Mateos, P. F., Martínez-Molina, E. \& Velázquez, E. (2004). Xylanibacterium ulmi gen. nov., sp. nov., a novel xylanolytic member of the family Promicromonosporaceae. Int $J$ Syst Evol Microbiol 54, 557-561.

Saddler, G. S., Tavecchia, P., Lociuro, S., Zanol, M., Colombo, L. \& Selva, E. (1991). Analysis of madurose and other actinomycete whole cell sugars by gas chromatography. J Microbiol Methods 14, 185-191.

Schleifer, K. H. (1985). Analysis of the chemical composition and primary structure of murein. Methods Microbiol 18, 123-156.

Schleifer, K. H. \& Kandler, O. (1972). Peptidoglycan types of bacterial cell walls and their taxonomic implications. Bacteriol Rev 36, 407-477.

Smibert, R. M. \& Krieg, N. R. (1994). Phenotypic characterization. Methods Gen Mol Bacteriol 25, 607-654.

Stackebrandt, E. \& Schumann, P. (2004). Reclassification of Promicromonospora pachnodae Cazemier et al. 2004 as Xylanimicrobium pachnodae gen. nov., comb. nov. Int J Syst Evol Microbiol 54, 1383-1386.

Stackebrandt, E., Schumann, P. \& Cui, X.-L. (2004). Reclassification of Cellulosimicrobium variabile Bakalidou et al. 2002 as Isoptericola variabilis gen. nov. comb. nov. Int J Syst Evol Microbiol 54, 685-688.

Uchida, K. \& Aida, K. (1984). An improved method for the glycolate test for simple identification of the acyl type of bacteria cell walls. J Gen Appl Microbiol 30, 131-134.

Yokota, A., Takeuchi, M., Sakane, T. \& Weiss, N. (1993). Proposal of six new species of the genus Aureobacterium and transfer of Flavobacterium esteraromaticum Omelianski to the genus Aureobacterium as Aureobacterium esteraromaticum comb. nov. Int J Syst Bacteriol 43, $555-564$. 